Article

\title{
Effect on the Thermal Properties of Mortar Blocks by Using Recycled Glass and Its Application for Social Dwellings
}

\author{
Vicente Flores-Alés ${ }^{1}{ }^{\mathbb{D}}$, Alexis Pérez-Fargallo ${ }^{2}{ }^{\mathbb{D}}$, Jesús A. Pulido Arcas $^{3}$ and \\ Carlos Rubio-Bellido $1, *$ (D) \\ 1 Department of Building Construction II, Universidad de Sevilla, 41012 Seville, Spain; vflores@us.es \\ 2 Department of Building Science, University of Bío-Bío, Concepción 1202, Chile; aperezf@ubiobio.cl \\ 3 Center for Research and Development of Higher Education, Graduate School of Arts and Sciences, College of \\ Arts and Sciences, The University of Tokyo, Meguro City, Tokyo 153-8907, Japan; jpulido@g.ecc.u-tokyo.ac.jp \\ * Correspondence: carlosrubio@us.es; Tel.: +34-686-135-595
}

Received: 25 September 2020; Accepted: 29 October 2020; Published: 31 October 2020

check for updates

\begin{abstract}
Including recycled waste material in cement mixes, as substitutes for natural aggregates, has resulted in diverse research projects, normally focused on mechanical capacities. In the case of recycled glass as an aggregate, this provides a noticeable improvement in thermal properties, depending on its dosage. This idea raises possible construction solutions that reduce the environmental impact and improves thermal behavior. For this research, an extended building typology that is susceptible to experiencing the risk of energy poverty has been chosen. The typology is typical for social housing, built using mortar blocks with crushed glass. First, the basic thermophysical properties of the mortars were determined by laboratory tests; after that, the dynamic thermal properties of representative constructive solutions using these mortars were simulated in seven representative climate zones in Chile. An analysis methodology based on periodic thermal transmittance, adaptive comfort levels and energy demand was run for the 21 proposed models. In addition, the results show that thermal comfort hours increases significantly in thermal zones 1, 2, 3 and 6; from $23 \mathrm{~h}$ up to $199 \mathrm{~h}$ during a year. It is in these zones where the distance with respect to the neutral temperature of the $\mathrm{m} 50$ solution reduces that of the $\mathrm{m} 25$ solution by half; i.e., in zone 1 , from $-429^{\circ} \mathrm{C}$ with the $\mathrm{m} 25$ solution to $-864{ }^{\circ} \mathrm{C}$ with the m50. This research intends to be a starting point to generate an analysis methodology for construction solutions in the built environment, from the point of view of thermal comfort.
\end{abstract}

Keywords: crushed glass; periodic thermal transmittance; energy demand; adaptive comfort; social housing

\section{Introduction}

The average glass recycling rate in the European Union (28 member countries) has reached a $76 \%$ threshold for the first time. This means that more than 12.4 million tons of glass were collected throughout the European Union in 2017, 2\% more than in 2016 [1,2]. The proportion of recycled glass in the US is currently estimated to be around $35 \%$. There is very little reliable data available for other countries. In the case of China, the recycling rate for container glass is currently still below $20 \%$ and in South Africa it is over 41\% [3]. It is important to highlight the impact of domestic recycling in a recovery chain of simple and safe containers. Glass is inert and maintains its inherent properties regardless of how many times it has been recycled. If suitably collected, it can be recycled ad infinitum in a closed circuit, hence repeatedly using this waste will help preserve the natural resources of the Earth, minimizing landfill spaces and saving energy and money [4]. 


\subsection{Effect of Crushed Glass on Thermal and Mechanical Properties of Mortars}

Cement mixes have traditionally been researched as construction products, in particular incorporating inert aggregates with sufficient resistance capacity to be substitutes of the virgin aggregate, with the ultimate goal of reducing the environmental impact associated with gravel and sand extraction. The chemical composition of glass mainly has a formless siliceous nature, which makes it compatible with natural aggregates, although when a very small size particle is used $(<20 \mu \mathrm{m})$ [5], it has a reactive nature induced by the high alkalinity of cement [6]. The alkalinity of glass causes the breakdown of the matrix favoring, by its formless nature, the formation of calcium silicate hydrate, improving the cementitious performance [7]. The fine particles of glass have a high specific surface [8] and therefore favor high pozzolanic reaction kinetics due to the strong reaction between the alkali in the cement and the reactive silica in the glass [9]. It must also be considered that glass can intervene in alkali aggregate reactions, although the participation of recycled material in this reaction depends on the particle size, with an expansive phenomena of sizes above $1 \mathrm{~mm}$ being favored [10]. In fact, the research made shows that fine waste glass has a mitigating capacity of the ASR [11]. Finally, it is worth mentioning that there are incipient studies which address the capacity that incorporating glass into cement mortar provides to improve the resistance to the penetration of chlorides $[12,13]$, and to develop bactericidal features [14,15].

Regarding resistance, several researchers have shown that crushed glass increases compression resistance [16,17], although the data has a significant spread in the results, obtaining optimal improvement percentages of between $10 \%$ and $30 \%$ compared to the reference mortar, depending on mortar type and the maximum size of the glass [18]. Regardless of the aggregate substitution, the dose conditions, and especially the w/c ratio, are determining factors in the mechanical behavior of the product [19]. In addition, Castro and de Brito (2013), regarding the mechanical behavior, showed a general improvement in terms of resistance to the carbonatation of concretes that contain glass waste (size $<4 \mathrm{~mm}$ ) as a natural fine aggregate [20].

Likewise, previous research has highlighted the capacity of glass aggregate as a substitute for sand to substantially reduce the thermal conductivity of mortar [21], demonstrating that energy savings can be achieved when using a glass aggregate instead of the sand alternative [22]. Sikora et al. have shown that substituting fine sand by WG can improve the thermal properties of cement mortars, while maintaining an acceptable mechanical strength [23].

\subsection{Low-Cost Materials and Its Application to Energy-Efficient Dwellings}

In the last few years, the building industry has been striving to reduce its energy consumption, and one of its strategies for this focuses on using recycled products as a construction material. In this sense, since crushed glass has beneficial effects on the thermal conductivity of mortars, is easy to obtain and has a low price, it has emerged as a viable option. Since crushed glass has a controversial effect on the mechanical properties, its use in structural elements is out of the question, being rather applied to coatings and finishing without structural function, but where thermal insulation becomes crucial to reduce the energy demands of the building.

Research on mortar blocks brings the opportunity of introducing an affordable material that also allows for a better insulation, as suggested by other authors [24], and finds a specific application in projects with limited financial resources, such as those comprising social dwellings. The use of recycled glass has wider implications, it is an environmentally friendly material, an affordable constructive solution and is technically feasible, even in countries where manpower has limited technical skills [25]. Previous research by the authors has focused on clarifying the feasibility of such materials on the basis of its chemical, mineralogical, physical, thermal and mechanical properties, and former studies claim that a percentage of recycled glass between $25 \%$ and $50 \%$ results in mortars with a lower thermal conductivity and higher density that, at the same time, have mechanical capacities comparable to mortars with natural aggregates $[26,27]$. 
Up to date, the great majority of studies in the field, as well as building codes, use the static thermal transmittance as a proxy for assessing the insulation capacity of a given material. Nevertheless, this approach ignores the complex interplay among other variables, such as the thermal inertia [28], which, in combination with the former, exerts a remarkable influence on the energy performance of buildings [29]. Static thermal transmittance relies on a simplification, where the temperature gap between the interior and the exterior of the building is constant, disregarding the effect that warm and cold climates with wide thermal oscillations might have on the energy demand of the building [30]. Recently, the UNE-EN ISO 13786 Standard [31] has taken the lead in incorporating the so-called dynamic thermal properties of building materials. In brief, this document assumes that heat flow between both sides of the envelope depends on the dynamic variation of the temperature gap through time. Starting with the calculation procedure as per the UNE-EN ISO 6946 [32], this standard considers both the static and the dynamic thermal transmittance.

Being this a novel approach, research on this area is still limited, but some researchers have already shed light on this, suggesting that periodic thermal transmittance can lead to a reduction in the energy demand of the building [33]; the authors have also made a contribution in this field, claiming that not static thermal transmittance, but thermal inertia, is the driver to improve indoor thermal comfort in social dwellings located in the Central-South area of Chile [34]. However, research in this field is still scarce and fragmented. Plenty of studies deal with the development of a new construction material with improved static thermal transmittance that, after determination of its properties by laboratory test, is applied to common constructive solutions. In the case of dynamic thermal properties, the process is more complex and there is still a research gap in considering studies that comprise the whole process: Determination of the properties by laboratory tests, implementation of the material in constructive solutions, and analysis of the effect on different aspects of energy demand and building comfort.

This study aims at filling-in this research gap by presenting a study comprising all these steps. In turn, the results of this study are expected to be applied to the design and construction of social dwellings in Chile. Subsidized housing always represents a challenge for designers and builders, as it needs to balance the constraints of a limited construction budget with the need of providing the lower strata of society with decent living standards. Chile is a representative case study for two reasons: First, this country encompasses a great variety of climates, including hot dry deserts in the North and cold steppes in the South. Second, this country has had a continuous and solid program of social dwellings, with 3.6 million subsidies granted between 1.964 and 2.015, and an estimated investment of 19 billion Euros since 1.990 [35]. At the present time, Supreme Decrees 01 and 49 establish the basic technical standards for social dwellings [36-39], which consist of predefined typologies with standardized constructive solutions: Built surfaces are between 36 and $55 \mathrm{~m}^{2}$ and usually have a living-dining area, a kitchen, a bathroom and two or three bedrooms. Considerations of energy efficiency were introduced only after the enactment of the General Urbanism and Constructions Ordinance (OGUC, in Spanish) in 2007 [40], which was the first legislation that established the limits for the U-values of the external envelope in Chilean buildings. After this, the government has put much effort into improving the benchmark for energy efficiency by releasing technical guidelines that, although not mandatory, have started to impregnate professional practice in the country: The Standards for the Sustainable Construction of Housing, published in 2014, raised the benchmark for thermal envelopes but is still not mandatory [41].

This background describes a country that, in spite of an increasing awareness about energy efficiency in buildings, still has a long way to go. Chilean researchers have clarified how low insulated houses can have unacceptable low temperatures in winter, as low as $14^{\circ} \mathrm{C}$ [42], which, in turn, may lead to a higher prevalence of respiratory illnesses [43]. The thermal adaptation of users in central-southern Chile has its own particularities, but currently, from the adaptive thermal comfort models included in the standards, the model that is part of ASHRAE 55-2017 is the one with the most similarities to those of the users [42,44].

In sum, there is a need for comprehensive research on how recycled glass incorporated into construction blocks can improve both static and thermal properties of the thermal envelope, and on how these constructive solutions may find an application in social dwellings in Chile. 
The article is organized in three sections. First, the methodology used in the research is described, analyzing the following aspects: (i) types of construction solutions considered and stationary transmittance; (ii) considerations about the periodic thermal transmittance calculation of UNE-EN ISO 13786; (iii) definition of the case study and the thermal modeling; (iv) analysis of the studied climate zones; and (v) the approach of the comfort and energy demand analysis. Second, the results are presented and discussed. Finally, the main conclusions of the results obtained in the study are summarized.

\section{Materials and Methods}

\subsection{Thermopyshical Properties of the Material}

In previous works, the potential viability of the materials being studied has been clarified $[26,27,45]$, starting from the evaluation of the chemical, mineralogical, physical, thermal and mechanical characteristics, as well as the correlation with thermal conductivity coefficients [46]. The thermal conductivity results have confirmed that the doses with $25 \%$ and $50 \%$ of glass aggregate have thermal conductivity coefficients that are noticeably lower than those of the reference material, and also higher densities, maintaining a sufficient mechanical capacity compared with natural aggregate mortars (Table 1).

Table 1. Sand and glass composition of mortars used in the study, density of the end product ( $\rho$ ), and thermal conductivity $(\delta)$ at $30^{\circ} \mathrm{C}$.

\begin{tabular}{cccccc}
\hline & Cement & \% Sand & \% Glass & $\rho\left(\mathrm{g} / \mathrm{cm}^{3}\right)$ & $\delta(\mathrm{W} / \mathrm{Km})$ \\
\hline $\mathbf{m R}$ & 1 & 3 & 0 & 1.60 & 1.2884 \\
\hline $\mathbf{m} 25$ & 1 & 2.25 & 0.75 & 1.95 & 1.0589 \\
\hline $\mathbf{m} 50$ & 1 & 1.5 & 1.5 & 2.04 & 0.8662 \\
\hline
\end{tabular}

The particles were classified according to their size as per UNE EN 933-1:2012 standard (0.063, 0.125, $0.250,0.50,1.00,2.00 \mathrm{~mm}$ ) [30] and continuous particle size with maximum compactness were prepared in accordance with Fuller's curve (Figures 1 and 2) [28]. Thermal conductivity was determined by differential scanning calorimetry (MDSC) at $30{ }^{\circ} \mathrm{C}$, thermal diffusivity $\left(\mathrm{cm}^{2} / \mathrm{s}\right)$ and thermal conductivity (W/mK) were measured on Linseis measuring equipment (LFA 1600) and a DSC Q20-TA [35].

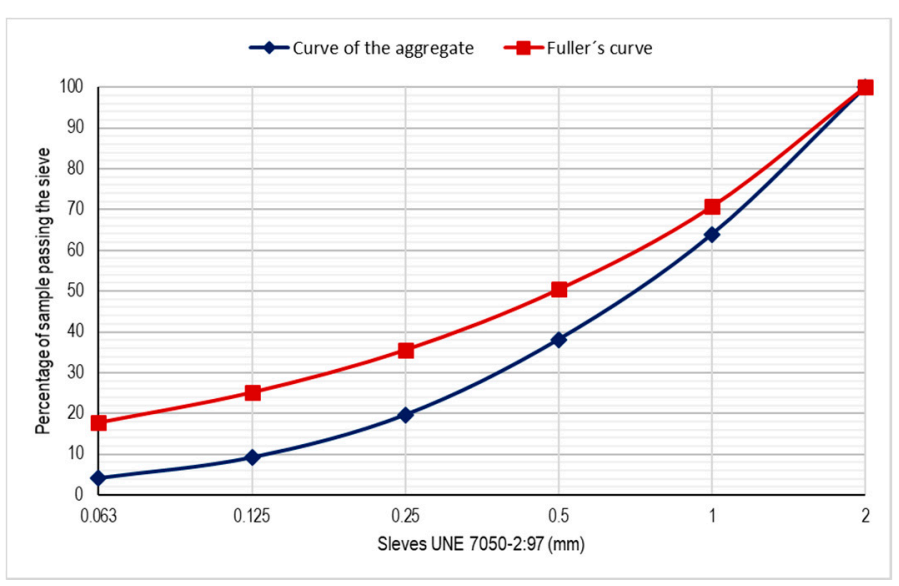

Figure 1. Aggregate particle size of crushed glass. Reprinted from Flores-Alés, V., Alducin-Ochoa, J. M., Martín-del-Río, J. J., Torres-González, M., and Jiménez-Bayarri, V. (2020). Physical-mechanical behaviour and transformations at high temperature in a cement mortar with waste glass as aggregate. Journal of Building Engineering, 29, 101158. 


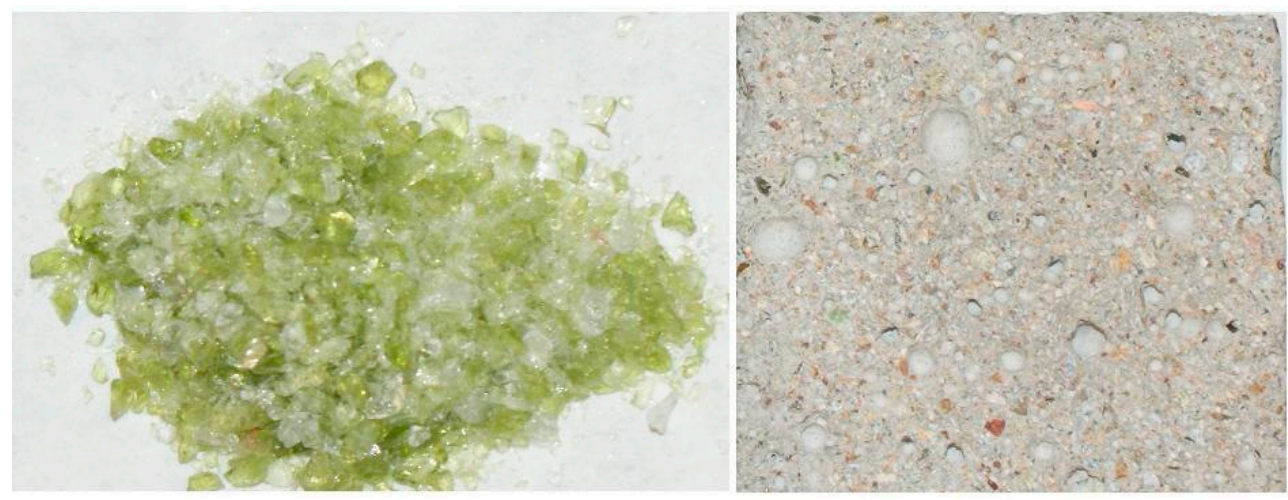

Figure 2. Crushed glass and mortar based on recycled glass as aggregate.

\subsection{Constructive Solutions and Static Thermal Properties}

This study considered three constructive solutions, which are commonplace in the construction of dwellings. Mortar blocks with a thickness of $11.5 \mathrm{~cm}$ constitute the core of the external walls; they are coated by a layer of cement mortar on the outside and plaster on the inside. The three solutions differ in the percentage of crushed glass used to elaborate the mortar blocks (mR, m25 and m50) which, in turn, modified their static properties: Thermal conductivity, gross density and specific heat capacity (Table 2). It is remarkable how higher percentages of crushed glass brings lower thermal conductivities and higher densities, while maintaining a nearly constant specific heat capacity.

Table 2. $15 \mathrm{~cm}$ brick thermal transmittance: $\mathrm{mR}, \mathrm{m} 25, \mathrm{~m} 50$.

\begin{tabular}{|c|c|c|c|c|c|c|}
\hline & Layer Name & $\begin{array}{c}\text { Thermal } \\
\text { Conductivity } \\
1(\mathrm{~W} / \mathrm{mK})\end{array}$ & $\begin{array}{c}\text { Gross } \\
\text { Density r } \\
\left(\mathrm{kg} / \mathrm{m}^{3}\right)\end{array}$ & $\begin{array}{l}\text { Spec. Heat } \\
\text { Capacity C } \\
\text { (J/kgK) }\end{array}$ & $\begin{array}{c}\text { Layer } \\
\text { Thickness d } \\
\text { (m) }\end{array}$ & $\underset{\left(\mathrm{m}^{2} \mathrm{~K} / \mathrm{W}\right)}{\mathrm{R}}$ \\
\hline \multirow{6}{*}{$\mathrm{mR}$} & \multicolumn{5}{|c|}{ Rsi (int. heat transfer resistance) } & 0.13 \\
\hline & Plaster & 0.570 & 1150.0 & 1000 & 0.0150 & 0.026 \\
\hline & Glass mortar $\mathrm{mR}$ brick & 1.288 & 1603.0 & 659 & 0.1150 & 0.089 \\
\hline & Cement mortar & 1.400 & 2000.0 & 800 & 0.0200 & 0.014 \\
\hline & \multirow{2}{*}{\multicolumn{2}{|c|}{ Rse (ext. heat transfer resistance) }} & & & & 0.04 \\
\hline & & & U-value: & 3.3349 & $W / m^{2} K$ & \\
\hline \multirow{6}{*}{$\mathrm{m} 25$} & \multicolumn{5}{|c|}{ Rsi (int. heat transfer resistance) } & 0.13 \\
\hline & Plaster & 0.570 & 1150.0 & 1000 & 0.0150 & 0.026 \\
\hline & Glass mortar mR25 brick & 1.059 & 1951.0 & 671 & 0.1150 & 0.109 \\
\hline & Cement mortar & 1.400 & 2000.0 & 800 & 0.0200 & 0.014 \\
\hline & \multirow{2}{*}{\multicolumn{2}{|c|}{ Rse (ext. heat transfer resistance) }} & & & & 0.04 \\
\hline & & & U-value: & 3.1329 & $W / m^{2} K$ & \\
\hline \multirow{6}{*}{ m50 } & \multicolumn{2}{|c|}{ Rsi (int. heat transfer resistance) } & & & & 0.13 \\
\hline & Plaster & 0.570 & 1150.0 & 1000 & 0.0150 & 0.026 \\
\hline & Glass mortar mR50 brick & 0.866 & 2039.0 & 687 & 0.1150 & 0.133 \\
\hline & Cement mortar & 1.400 & 2000.0 & 800 & 0.0200 & 0.014 \\
\hline & \multirow{2}{*}{\multicolumn{2}{|c|}{ Rse (ext. heat transfer resistance) }} & & & & 0.04 \\
\hline & & & U-value: & 2.9124 & $W / m^{2} K$ & \\
\hline
\end{tabular}

\subsection{Assumption of Periodic Thermal Transmittance and Dynamic Thermal Properties}

The UNE-EN ISO 13786 standard defines the analytical calculation procedure and the parameters related to the dynamic thermal behavior of building envelopes [31]. The theoretical basis of this was 
primarily established by Carslaw and Jaeger [47], who analyzed the sinusoidal ratio between the heat flow and the indoor and outdoor temperatures. The oscillation period $(\mathrm{T})$ of the temperatures can be an hour, a day or a year, and this research assumes that the sinusoidal variation has a period of 1 day, which corresponds to the daily oscillations of the external temperatures [31]. After this, three static properties of all the considered materials must be known: thermal conductivity $(\lambda)$, density $(\rho)$, and specific thermal capacity (c). In this case, they were already determined by laboratory tests. Thermal bridges do not have to be considered due to their low impact on dynamic thermal properties [31].

The calculation procedure uses the thermal transference matrices for each one of the homogeneous layers of the wall $\left(Z_{m n}\right)$. The elements of a transference matrix are defined as (Equation (1)):

$$
\begin{aligned}
& Z_{m n}=\left(\begin{array}{ll}
Z_{11} & Z_{12} \\
Z_{21} & Z_{22}
\end{array}\right) \\
& Z_{11}=Z_{22}=\cosh (\xi) \cos (\xi)+j \cdot \operatorname{senh}(\xi) \operatorname{sen}(\xi) \\
& Z_{12}=-\frac{\delta}{2 \lambda}\{\operatorname{senh}(\xi) \cos (\xi)+\cosh (\xi) \operatorname{sen}(\xi)+j \cdot[\cosh (\xi) \operatorname{sen}(\xi)-\operatorname{senh}(\xi) \cos (\xi)]\} \\
& Z_{21}=-\frac{\lambda}{\delta}\{\operatorname{senh}(\xi) \cos (\xi)-\cosh (\xi) \operatorname{sen}(\xi)+j \cdot[\cosh (\xi) \operatorname{sen}(\xi)+\operatorname{senh}(\xi) \cos (\xi)]\}
\end{aligned}
$$

where $\delta(\mathrm{m})$ is the periodic penetration depth of a thermal wave on the layer's material (Equation (2)), and $\xi$ (dimensionless) is the ratio between $d$ and $\delta$ (Equation (3)).

$$
\begin{gathered}
\delta=\sqrt{\frac{\lambda T}{\pi \rho c}} \\
\xi=\frac{d}{\delta}
\end{gathered}
$$

The transference matrix of a wall $(Z)$ is defined as the multiplication of the matrices of the different layers $\left(Z_{i}\right)$ from the outside $(i=N)$ to the inside $(i=1)$ :

$$
Z=\left(\begin{array}{ll}
Z_{11} & Z_{12} \\
Z_{21} & Z_{22}
\end{array}\right)=\prod_{i=N}^{1} Z_{i}
$$

The different periodic variables can be determined by operating the elements of the matrix. The periodic variables defined in UNE-EN ISO 13786, and considered in the study, are: (i) periodic thermal transmittance $\left(\left|Y_{12}\right|\right)\left(\mathrm{W} /\left(\mathrm{m}^{2} \mathrm{~K}\right)\right)$, which is the module of the complex number defined as the complex amplitude of the heat flow density through the indoor component's surface, divided by the complex amplitude of the temperature of the outdoor area, when the indoor temperature is constant (Equation (5)); (ii) time shift periodic thermal transmittance $(\varphi)(\mathrm{h})$, which is the period of time between the maximum amplitude of a cause and the maximum amplitude of its effect, related to the periodic thermal transmittance (Equation (6)); (iii) decrement factor (f) (dimensionless), which is the quotient between the periodic thermal transmittance module and the U-value (Equation (7)); (iv) internal thermal admittance $\left(\left|Y_{11}\right|\right)\left(\mathrm{W} /\left(\mathrm{m}^{2} \mathrm{~K}\right)\right)$, which is the complex number module defined as the complex amplitude of the heat flow density through the surface of the component adjoining the indoor area, divided by the complex amplitude of the temperature in the same area when the indoor temperature is kept constant (Equation (8)); (v) time shift internal side $\left(\varphi_{11}\right)(\mathrm{h})$, which is the period of time between the maximum amplitude of a cause and the maximum amplitude of its effect, related to the internal thermal admittance (Equation (9)); (vi) external thermal admittance $\left(\left|Y_{22}\right|\right)\left(\mathrm{W} /\left(\mathrm{m}^{2} \mathrm{~K}\right)\right)$, which is the complex number module defined as the complex amplitude of the heat flow density through the surface of the component adjoining the outdoor area, divided by the complex amplitude of the temperature in the same area when the outdoor temperature remains constant (Equation (10)); and (vii) time shift external side $\left(\varphi_{22}\right)(\mathrm{h})$, which is the period of time between the maximum amplitude of a cause and the maximum amplitude of its effect related to the external thermal admittance (Equation (11)). 


$$
\begin{gathered}
Y_{12}=-\frac{1}{Z_{12}} \\
\varphi=\frac{T}{2 \pi} \arg \left(Z_{12}\right) \\
f=\frac{\left|Y_{12}\right|}{U} \\
Y_{11}=-\frac{Z_{11}}{Z_{12}} \\
\varphi_{11}=\frac{T}{2 \pi} \arg \left(Y_{11}\right) \\
Y_{22}=-\frac{Z_{22}}{Z_{12}} \\
\varphi_{22}=\frac{T}{2 \pi} \arg \left(Y_{22}\right)
\end{gathered}
$$

\subsection{Case Study and Thermal Model}

Figure 3 shows housing model for the study.

A representative case-study was selected from the Project Bank of the Bio-Bio Region's Housing and Urbanization Service (SERVIU, in Spanish) [37]; a detached house with a higher surface of thermal envelope (external walls, roof and slabs) would have, a priori, a worse energy performance in this climate [38]. The prototype was modelled in the EnergyPlus ${ }^{\circledR}$ simulation software [36] and parametric simulations were done considering the thermal constructive properties of Table 3. The base-case scenario considered U-values as per the Chilean Building code, and the thermal properties of three different walls were introduced, using the three different mortars considered (Table 2). Ventilation rates were adjusted as per the minimum values recommended by the Chilean standard. In addition,

\begin{tabular}{|c|c|c|c|c|c|c|c|c|c|c|}
\hline Case & \multicolumn{2}{|r|}{$\begin{array}{l}\text { U Openings } \\
\left(\mathrm{W} / \mathrm{m}^{2} \mathrm{~K}\right)\end{array}$} & \multicolumn{3}{|c|}{$\mathrm{U}$ envelope $\left(\mathrm{W} / \mathrm{m}^{2} \mathrm{~K}\right)$} & \multicolumn{4}{|c|}{ Ventilation $1 /\left(s^{*}\right.$ Person $)$} & $\begin{array}{c}\text { Infiltrations } \\
\text { (ACh) }\end{array}$ \\
\hline 1 & $\mathrm{mR}$ & & & $3.916-0.600 *$ & & & & & & \\
\hline 2 & $\mathrm{~m} 25$ & $1.94-3.16$ * & $0.25-0.84$ * & $3.651-0.593$ * & 45 & $24 \mathrm{~h}$ & 5.2 & 5.2 & 5.2 & 1 \\
\hline 3 & $\mathrm{~m} 50$ & & & $3.367-0.585$ * & & & & & & \\
\hline
\end{tabular}
the values for internal loads, such as occupation, lighting, equipment and ventilation, were considered (Table 4), as well as their schedules (Figure 4).
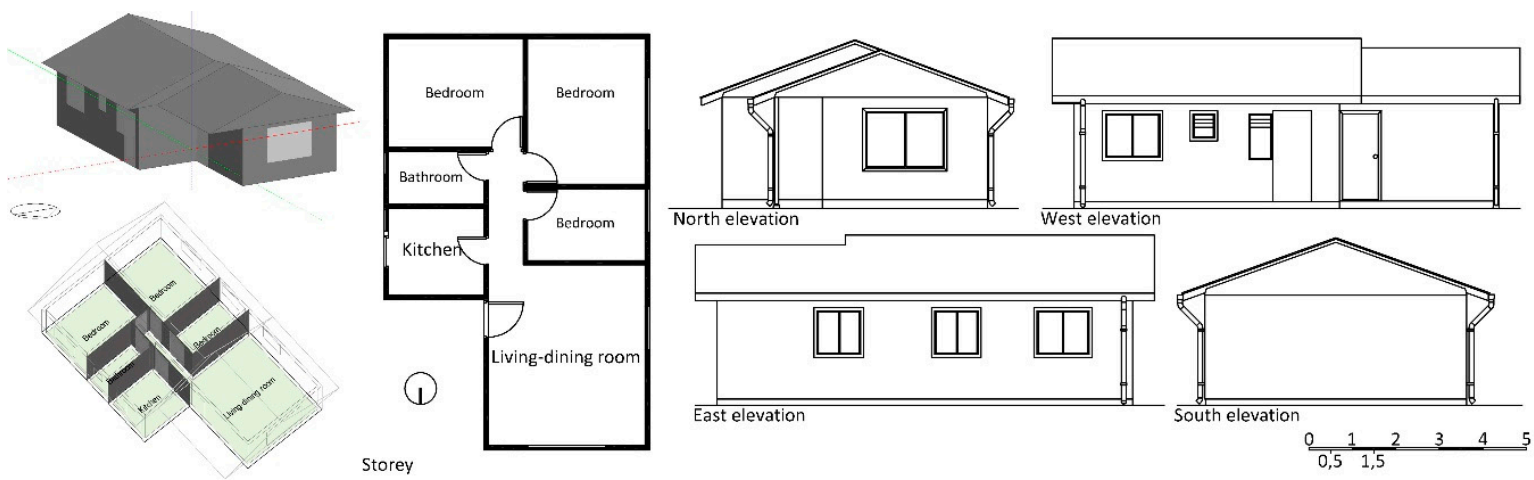

Figure 3. Housing model for the study.

Table 3. Thermal constructive properties of the case studies with the three bricks.

* Depends on the climate zone considered. 
Table 4. Internal heat loads for the models.

\begin{tabular}{cccccc}
\hline & Living-Dining Room & Kitchen & Bedroom & Bathroom & Corridor \\
\hline Illumination $\left(\mathbf{W} / \mathbf{m}^{\mathbf{2}}\right)$ & 23 & 13 & 12 & 13 & 5 \\
Occupation $\left(\mathbf{W} / \mathbf{m}^{\mathbf{2}}\right)$ & 8.9 & 8.9 & 8.9 & 8.9 & 8.9 \\
Equipment $\left(\mathbf{W} / \mathbf{m}^{\mathbf{2}}\right)$ & 12.40 & 12.40 & 12.40 & - & 12.40 \\
\hline
\end{tabular}

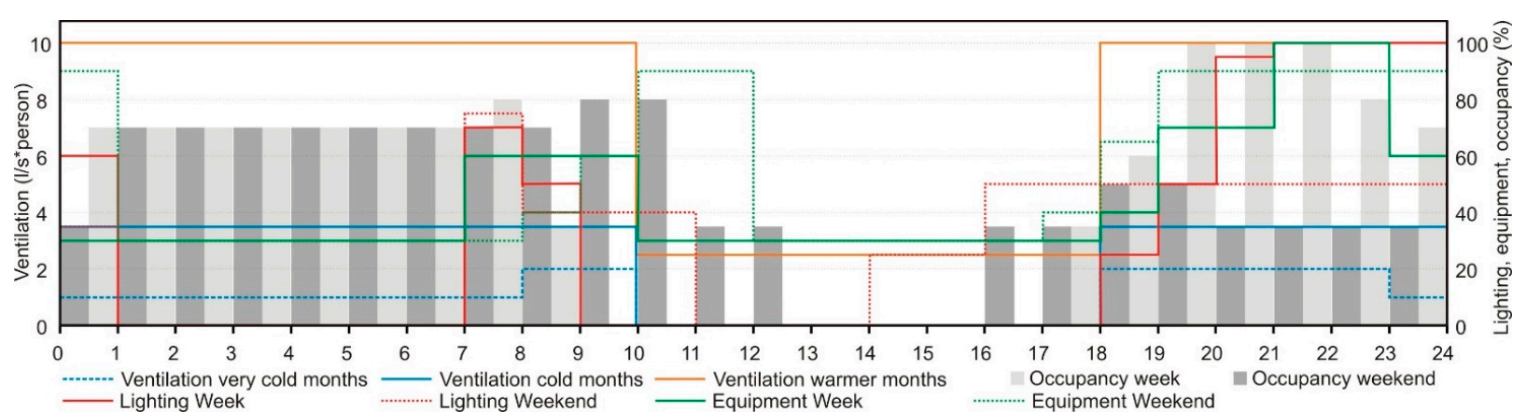

Figure 4. Occupation, lighting and equipment and ventilation schedules. Source: [34].

\subsection{Climate Zones}

Chile's climate varies greatly, covering the climatic variants B (arid and semi-arid), C (template) and E (cold) of the Köppen-Geiger classification. According to the current standard, Chile is divided into 7 thermal zones considering the annual heating degree days (Table 5) [48]. The Thermal Regulation (RT, in Spanish) for housing came into force in 2000. In a first stage, maximum thermal transmittance requirements were defined for roofs and, in a second stage in 2007, requirements were established for walls, ventilated floors and windows [49], which are mainly based on heating degree days. A representative city has been chosen for each of the 7 thermal zones, which also allows for an easy classification as per Köppen-Geiger (Table 5). An EPW weather file was considered for each city to model the external conditions.

Table 5. Selected locations from Chilean Climatic Zoning.

\begin{tabular}{|c|c|c|c|c|c|c|c|c|c|c|}
\hline Zone & Location & $\begin{array}{l}\text { Koppen-Geiger } \\
\text { Classification }\end{array}$ & Latitude & Longitude & Elevation & $\begin{array}{l}\text { Average } \\
\text { January }\end{array}$ & $\begin{array}{c}\text { Oscil. } \\
\text { January }\end{array}$ & $\begin{array}{l}\text { Average } \\
\text { July }\end{array}$ & $\begin{array}{l}\text { Oscil. } \\
\text { July }\end{array}$ & $\begin{array}{c}\text { Heating } \\
\text { Degree Day } \\
\text { Based on } \\
15^{\circ} \mathrm{C}\end{array}$ \\
\hline 1 & Antofagasta & BWk & $23.43^{\circ} \mathrm{S}$ & $70.43^{\circ} \mathrm{W}$ & $120 \mathrm{~m}$ & 20.5 & 7.3 & 14.9 & 5 & $\leq 500$ \\
\hline 2 & Valparaíso & CSbn & $30.03^{\circ} \mathrm{S}$ & $71.48^{\circ} \mathrm{W}$ & $41 \mathrm{~m}$ & 17.8 & 9.2 & 11.4 & 7.3 & $>500-\leq 750$ \\
\hline 3 & Santiago & $\mathrm{CSb}$ & $33.38^{\circ} \mathrm{S}$ & $70.78^{\circ} \mathrm{W}$ & $474 \mathrm{~m}$ & 20.7 & 17 & 7.9 & 11.3 & $>750-\leq 1000$ \\
\hline 4 & Concepción & CSbn's & $36.77^{\circ} \mathrm{S}$ & $73.05^{\circ} \mathrm{W}$ & $16 \mathrm{~m}$ & 16.6 & 14.2 & 8.7 & 8.5 & $>1000-\leq 1250$ \\
\hline 5 & Temuco & $\mathrm{CFb}$ & $38.75^{\circ} \mathrm{S}$ & $72.63^{\circ} \mathrm{W}$ & $120 \mathrm{~m}$ & 18.0 & 17.2 & 6.3 & 7.6 & $>1250-\leq 1500$ \\
\hline 6 & Lonquimay & $\mathrm{CFb}$ & $38.43^{\circ} \mathrm{S}$ & $71.23^{\circ} \mathrm{W}$ & $925 \mathrm{~m}$ & 15.5 & 20.9 & 1.5 & 9.4 & $>1500-\leq 2000$ \\
\hline 7 & $\begin{array}{l}\text { Punta } \\
\text { Arenas }\end{array}$ & BSk's & $53.00^{\circ} \mathrm{S}$ & $70.85^{\circ} \mathrm{W}$ & $37 \mathrm{~m}$ & 11.2 & 8.2 & 2.2 & 4.7 & $>2000$ \\
\hline
\end{tabular}

\subsection{Thermal Comfort and Energy Analysis}

The influence of using mortar bricks with glass in housing will be determined starting from the simulation results from EnergyPlus ${ }^{\circledR}$, using two thermal comfort indicators and four energy demand indicators. The comfort indicators will be obtained by simulating the dwelling in the seven climates with the three brick types ( $\mathrm{mR}, \mathrm{m} 25$ and $\mathrm{m} 50)$, in free oscillation during the entire year. With the results of the hourly operational temperatures in free oscillation, the number of annual hours where the operational temperatures are within the adaptive thermal comfort (ATC) limits of the model defined in the ASHRAE 55-2017 [44] standard, will be quantified, as will the distance in hourly operational temperature degrees to the thermal neutrality to quantify the reduction or increase of extremely hot or cold temperatures. In this case, a thermal acceptability limit of $80 \%$, as per ASHRAE 55-2017, was considered; Chile, as many other countries, still does not have its own standard for adaptive thermal comfort, thus international documents are adopted. ATC models were originally developed 
for office buildings [50], whereas they find also application in residential buildings, considering that occupants may change their clothes and operate windows to achieve thermal comfort [51]. Besides, previous studies also support the fact that adaptive comfort finds an application in naturally cooled houses, and finds applicability in social dwellings [42].

The ASHRAE adaptive model is governed by Equation 12, which defined the neutral temperature inside the building $\left(T_{n}\right)$ as a function of the $T_{\text {pma(out) }}$; a range of $\pm 3.5^{\circ} \mathrm{C}$ gives an acceptability of $80 \%$ and $\pm 2.5^{\circ} \mathrm{C}$ gives a $90 \%$.

$$
T_{n}=0.31 \times T_{\text {pma(out) }}+17.8
$$

$T_{\mathrm{pma}(\mathrm{out})}$ is a weighted average of the mean external temperatures of the previous 7 days (Equation (13)). $T_{e(d-1)}$ is the average outdoor temperature of the previous day, $T_{e(d-2)}$, the average outdoor temperature of two days prior and so on and so forth; and $\alpha$ is a constant that depends on the thermal oscillation of the local climates, assuming $\alpha=0.8$ [44].

$$
T_{\text {pma(out) }}=(1-\alpha) \times\left(T_{\mathrm{e}(\mathrm{d}-1)}+\alpha \times T_{\mathrm{e}(\mathrm{d}-2)}+\alpha^{2} \times T_{\mathrm{e}(\mathrm{d}-3)}+\alpha^{3} \times T_{\mathrm{e}(\mathrm{d}-4)}+\cdots\right)
$$

$\left(T_{\text {pma(out) }}\right)$ must be within $10.0^{\circ} \mathrm{C}$ and $33.5^{\circ} \mathrm{C}$ so that this standard find application. If $\left(T_{\text {pma(out) }}\right)$ falls outside those limits, the neutral temperature will be a constant, as the standard assumes that when it is too cold or too hot, active cooling or heating becomes necessary, thus internal temperatures are decoupled from the external oscillations. In that case, this study assumed a heating setpoint temperature of $20^{\circ} \mathrm{C}$ and a cooling setpoint of $26^{\circ} \mathrm{C}$, as per EN 16798 standard, Category II [52]. If necessary, the dwelling would have to resort to heating or cooling devices and therefore the energy demand was also recorded. Those variables were simulated for the 3 constructive solutions (Table 2) and the 7 climate zones of Chile (Table 5).

\section{Results and Discussion}

\subsection{Periodical Thermal Properties}

Taking the data as a base for the static thermal transmittance (Table 2), and following the calculation procedure described in Section 2.2, the periodic thermal properties of the 3 constructive solutions considered were calculated. Thermal conductivity $(\lambda)$, density $(\rho)$ and specific heat capacity (c) were already known for each solution; the calculation period for the thermal oscillation was $24 \mathrm{~h}$ for all cases, which is the recommended value for daily meteorological variations and temperature setback. The dynamic thermal properties were calculated (Table 6) using the tool to calculate thermal mass [53].

Table 6. Calculation results according to EN ISO 13786.

\begin{tabular}{ccccc}
\hline Parameter & Unit & mR & m25 & m50 \\
\hline external thermal admittance & $\mathrm{W} /\left(\mathrm{m}^{2} \mathrm{~K}\right)$ & 7.351 & 7.732 & 7.615 \\
time shift external side & $\mathrm{h}$ & 2.64 & 2.60 & 2.61 \\
internal thermal admittance & $\mathrm{W} /\left(\mathrm{m}^{2} \mathrm{~K}\right)$ & 4.068 & 4.132 & 4.085 \\
time shift internal side & $\mathrm{h}$ & 1.05 & 1.18 & 1.28 \\
periodic thermal transmittance & $\mathrm{W} /\left(\mathrm{m}^{2} \mathrm{~K}\right)$ & 2.890 & 2.548 & 2.280 \\
time shift periodic thermal transmittance & $\mathrm{h}$ & -2.68 & -3.26 & -3.63 \\
external areal heat capacity & $\mathrm{kJ} /\left(\mathrm{m}^{2} \mathrm{~K}\right)$ & 101.822 & 110.720 & 111.165 \\
Internal areal heat capacity & $\mathrm{kJ} /\left(\mathrm{m}^{2} \mathrm{~K}\right)$ & 47.083 & 53.592 & 56.158 \\
decrement factor $\mathrm{f}$ & & 0.866 & 0.813 & 0.783 \\
\hline
\end{tabular}

Static thermal transmittance could be reduced by around $13 \%$ on using recycled glass aggregates, and similar effects can be seen in the dynamic thermal properties, though the discussion there is more complex. Dynamic thermal transmittance was reduced by around $22 \%$; the decrement factor was reduced from 0.86 to $0.78(-10 \%)$, and the time shift was increased by one hour, which means that the thermal oscillation amplitude is reduced conjointly with a delay in the transmission of heat 
from the outside to the inside. This could be expected because of the greater heat capacity of the proposed material.

However, to fully grasp the real implications of these properties, additional data were needed. Since dynamic thermal properties are highly dependent on temperature oscillation, which, in turn, is a function of the local climate, it was deemed necessary to clarify how these solutions would work in all the climate zones of Chile. For this purpose, external temperature variations were simulated during a 24-h cycle, by approximating the oscillation to a cosine function in the form of:

$$
t(h)=t_{\text {avg }}+t_{\text {amp }} \times\left(\cos \left(t-t_{\max }\right)\right)
$$

where $t_{\text {avg }}$ is the daily average temperature, $t_{\text {amp }}$ is the daily temperature amplitude, $t$ is time in hours and $t_{\max }$ is the time of the day when the outdoor temperature reaches its maximum. As a result, this function delivers an output, $t(h)$, which is the hourly external temperature for $24 \mathrm{~h}$. Additional data were needed to calculate the temperature oscillation inside the building: The thermal resistance of the external air layer and the static thermal transmittance are obtained from Table 2; the external thermal admittance and the time shift for the external side are obtained from Table 6 . A calculation routine was written in Matlab ${ }^{\circledR}$, where the properties of the m50 solution (Table 6) and the climate data for each location (Table 5) were input, giving as a result the indoor and outdoor temperature oscillation for the coldest and hottest months of the year. No HVAC systems were considered, so the mere effect of the walls on the indoor environment could be clarified. Data were depicted graphically; the $\mathrm{x}$ axis was extended to $36 \mathrm{~h}$ and the scales of the $\mathrm{y}$ axis were unified for an easier comparison (Figure 5).

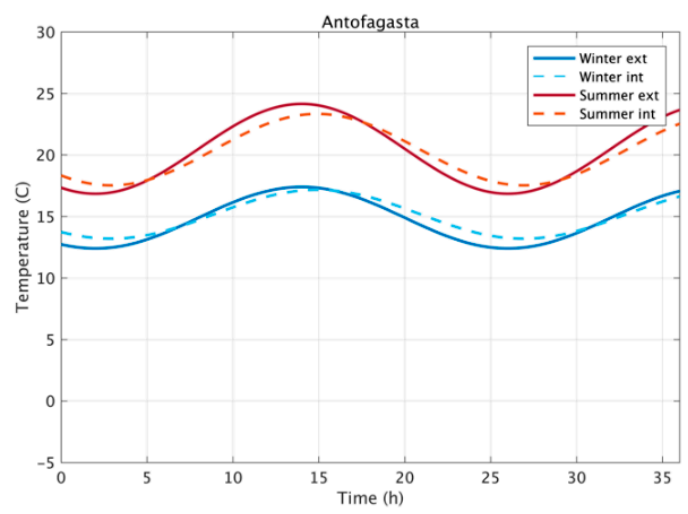

(a) Antofagasta

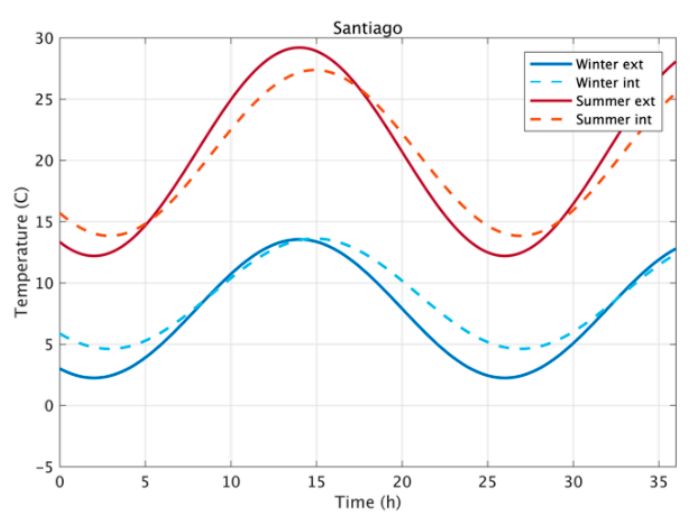

(c) Santiago

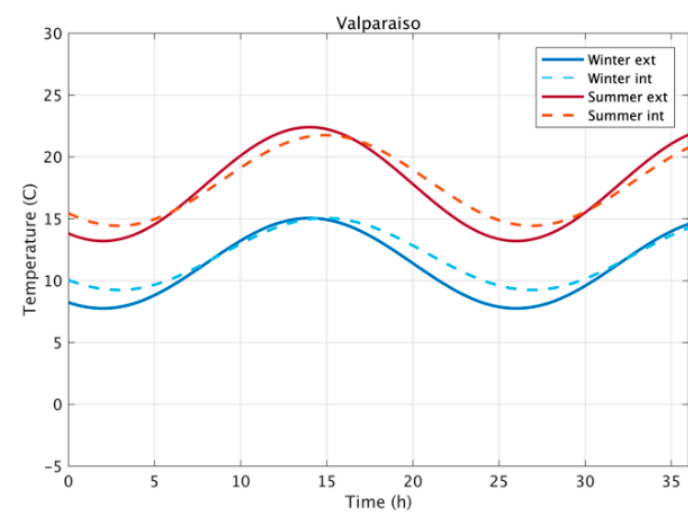

(b) Valparaiso

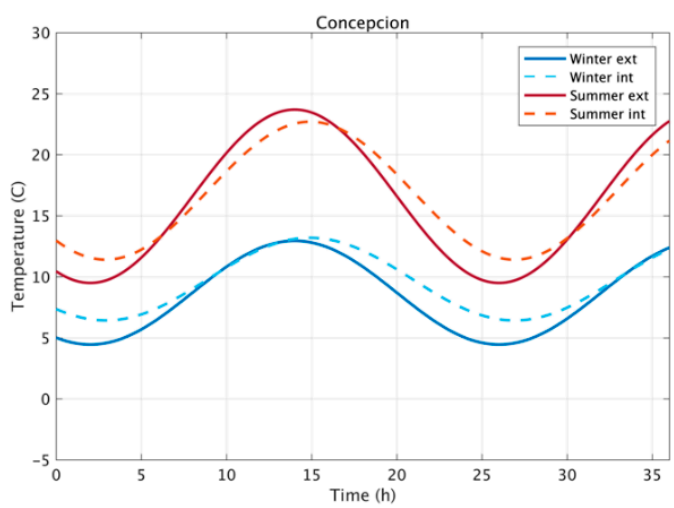

(d) Concepción

Figure 5. Cont. 


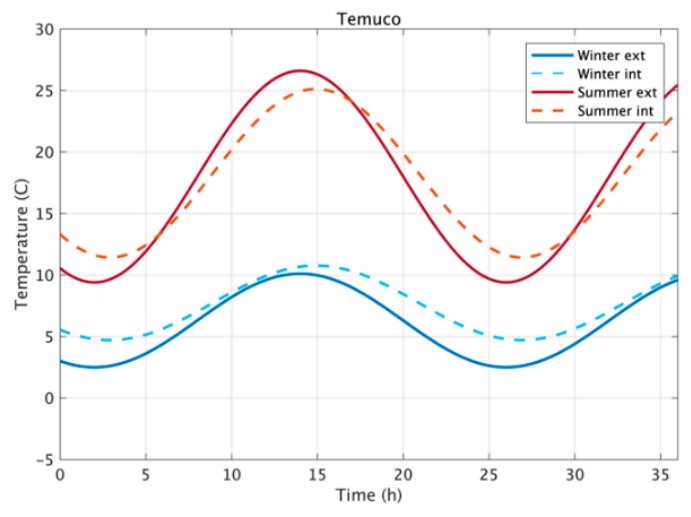

(e) Temuco

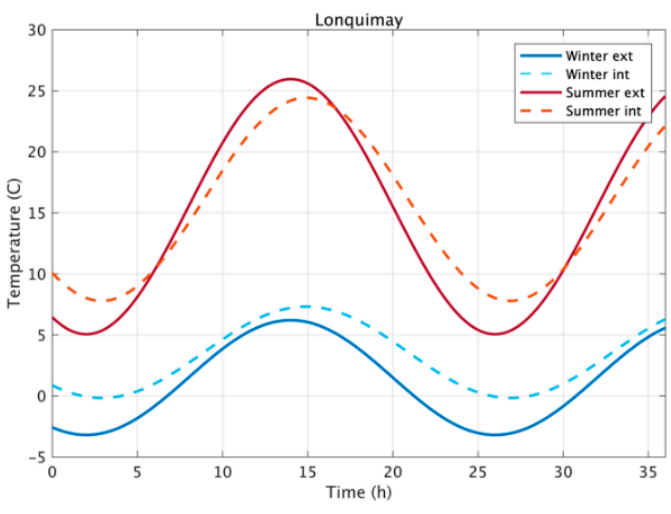

(f) Lonquimay

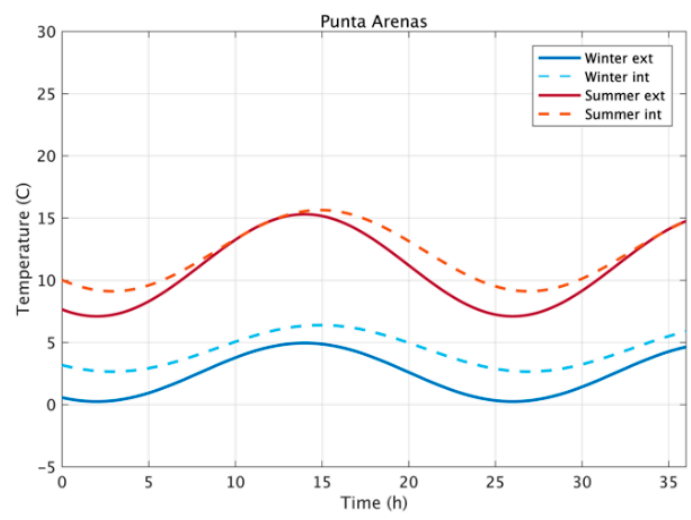

(g) Punta Arenas

Figure 5. Thermal oscillation of m50 solution, in winter and summer, for representative cities of the seven climate zones of Chile.

Two aspects of the results from these simulations can be commented on: Time shift and decrement factor. In general, this solution works better in climates with large thermal oscillations between day and night, such as Lonquimay or Santiago. During the cold season, indoor temperatures are never lower than outdoor temperatures; while on the contrary, during the hot season, thermal inversion is observed, and the walls can mitigate the low temperatures during the first few hours in the morning and also help in weathering the peak in temperature during the middle of the day. In regions with low thermal oscillation, whether we are talking about cold warm (Antofagasta) or cold climates (Punta Arenas), the effect is not so evident, although indoor temperatures are always a couple of degrees above outdoor temperatures during the cold season.

\subsection{Thermal Comfort and Energy Saving Analysis}

Dynamic simulations have been developed to establish the impact of glass aggregate mortars on the thermal behavior of social housing in the different thermal zones. The substitution of conventional mortar bricks for glass aggregate mortars can signify anywhere between a $1 \%$ and $14 \%$ reduction in the enclosure's thermal transmittance, maintaining the same total thickness and insulation (Table 7). This reduction in thermal transmittance, along with a higher thermal inertia, means that the use of said material in zones Z1, Z2, Z3 and Z6, results in an increase in thermal comfort hours when the dwelling operates under free oscillation. These are higher for the m50 mortar, ranging from 65 to $199 \mathrm{~h}$, while they range from 23 and 103 for the m 25 mortar. Therefore, the increase in recycled glass percentage has a direct relationship on the increase in hours in comfort for climates where the increase in thermal inertia this material provides, can be taken advantage of. 
Table 7. Hours in thermal comfort and distance in respect to the neutral temperature by zones considering the mortar used.

\begin{tabular}{|c|c|c|c|c|c|c|c|}
\hline \multirow{2}{*}{ ZONE } & \multirow{2}{*}{ Mortar } & \multicolumn{2}{|c|}{ Transmittance $\left(\mathrm{W} / \mathrm{m}^{2} \mathrm{~K}\right)$} & \multicolumn{2}{|c|}{ Hours in Comfort (h) } & \multicolumn{2}{|c|}{ Distance to $\operatorname{Tn}\left({ }^{\circ} \mathrm{C}\right)$} \\
\hline & & & uction $(\%)$ & & rence $(h$ & & erence $\left({ }^{\circ} \mathrm{C}\right)$ \\
\hline \multirow{4}{*}{$\mathrm{Z1}$} & $\mathrm{mR}$ & 3.916 & & 6351 & & 21,157 & \\
\hline & $\mathrm{m} 25$ & 3.651 & $7 \%$ & 6454 & 103 & 20,728 & -429 \\
\hline & $\mathrm{m} 50$ & 3.367 & $14 \%$ & 6550 & 199 & 20,293 & -864 \\
\hline & $\mathrm{mR}$ & 3.004 & & 4128 & & 35,404 & \\
\hline \multirow[t]{3}{*}{$\mathrm{Z2}$} & $\mathrm{m} 25$ & 2.846 & $5 \%$ & 4151 & 23 & 34,995 & -409 \\
\hline & m50 & 2.670 & $11 \%$ & 4198 & 70 & 34,583 & -822 \\
\hline & $\mathrm{mR}$ & 1.903 & & 4390 & & 32,583 & \\
\hline \multirow[t]{3}{*}{$\mathrm{Z3}$} & $\mathrm{m} 25$ & 1.839 & $3 \%$ & 4437 & 47 & 32,327 & -255 \\
\hline & $\mathrm{m} 50$ & 1.764 & $7 \%$ & 4464 & 74 & 32,083 & -500 \\
\hline & $\mathrm{mR}$ & 1.701 & & 5031 & & 28,727 & \\
\hline \multirow[t]{3}{*}{$\mathrm{Z} 4$} & $\mathrm{~m} 25$ & 1.649 & $3 \%$ & 4998 & -33 & 28,897 & 170 \\
\hline & $\mathrm{m} 50$ & 1.589 & $7 \%$ & 5056 & 25 & 28,544 & -183 \\
\hline & $\mathrm{mR}$ & 1.599 & & 4238 & & 35,646 & \\
\hline \multirow[t]{3}{*}{$\mathrm{Z} 5$} & $\mathrm{~m} 25$ & 1.553 & $3 \%$ & 4238 & 0 & 35,888 & 242 \\
\hline & m50 & 1.499 & $6 \%$ & 4275 & 37 & 35,523 & -122 \\
\hline & $\mathrm{mR}$ & 1.101 & & 4296 & & 36,363 & \\
\hline \multirow[t]{3}{*}{ Z6 } & $\mathrm{m} 25$ & 1.079 & $2 \%$ & 4330 & 34 & 36,096 & -267 \\
\hline & $\mathrm{m} 50$ & 1.053 & $4 \%$ & 4361 & 65 & 35,875 & -488 \\
\hline & $\mathrm{mR}$ & 0.600 & & 2676 & & 55,647 & \\
\hline \multirow[t]{2}{*}{$\mathrm{Z7}$} & $\mathrm{m} 25$ & 0.593 & $1 \%$ & 2605 & -71 & 56,178 & 531 \\
\hline & $\mathrm{m} 50$ & 0.585 & $3 \%$ & 2618 & -58 & 56,048 & 401 \\
\hline
\end{tabular}

There are thermal zones, such as Z4 and Z5, where it is necessary to exceed $25 \%$ in the substitution of aggregate for glass so that there is a positive impact; however, this impact is not as important as in zones Z1, Z2, Z3 and Z6. For zone 7 (Punta Arenas), none of the glass aggregate mortars have an increase of comfort hours due to their low daily oscillation during the coldest months, just as was commented in Section 3.1. However, in zone 1 (Antofagasta), there is a significant increase in hours, despite this not being a climate with major thermal oscillations. This is due to the proximity of outdoor hours to the comfort limits (See Table 5).

The distance regarding neutral temperature marked by the ASHRAE adaptive comfort model has also seen important reductions in zones 1, 2, 3 and 6, with the m50 mortar representing almost double the reduction compared to the $\mathrm{m} 25$ in these zones. Zone 7 , just as in the difference in the results of comfort hours, does not see a reduction in this indicator, as the distance increases by $401{ }^{\circ} \mathrm{C}$ for $\mathrm{m} 50$ and $531{ }^{\circ} \mathrm{C}$ for $\mathrm{m} 25$. Zones $\mathrm{Z} 4$ and $\mathrm{Z} 5$ only have a reduction of the distance when the m50 mortar is used, and end up being $-183^{\circ} \mathrm{C}$ and $-122^{\circ} \mathrm{C}$, respectively (See Table 7).

These results are associated with a higher thermal comfort and lower overheating issues in dwellings for zones 1, 2, 3 and 6 when these operate under free oscillation. Said results can also assume a reduction in respect to heating and cooling consumptions, as well as in demand peaks due to a lower thermal oscillation inside the dwelling, linked with a higher thermal inertia of the enclosures. In Table 8 , it can be seen that heating peak demands can be reduced by between $0.1 \%$ and $7.6 \%$, with zones $\mathrm{Z1}$ and Z2 providing a higher reduction (2.6-7.6\%). The same occurs with the heating demand, with reductions of between $3.4 \%$ and $15.3 \%$. In these zones, the use of an m50 mortar assumes a $50 \%$ increase in consumption reduction compared to the m25, with Z1 passing from 2667 to $2559 \mathrm{KWh} /$ year and Z2 from 7047 to $6557 \mathrm{KWh} /$ year.

The cooling demand and peaks also see important reductions in zones Z1, Z2 and Z3 (in the rest of the zones there is no cooling demand) (See Table 8). The reductions of the cooling peak oscillate between $4.8 \%$ and $12.2 \%$, falling in the most favorable zone, $\mathrm{Z1}$, from 4.14 to $3.64 \mathrm{kWh}$. The reductions for cooling demand are between $7.3 \%$ and $9.8 \%$, with reductions seeing a noticeably similar percentage 
among the three zones. However, the kWh reduction oscillates between 150 and $366 \mathrm{KWh} / \mathrm{year}$, with the zones providing a better performance, with glass aggregate mortar being in zones 2 and 3 , respectively.

Table 8. Heating and cooling demand and peak by zones, depending on mortar used.

\begin{tabular}{|c|c|c|c|c|c|c|c|c|c|}
\hline \multirow[b]{2}{*}{ ZONE } & \multirow[b]{2}{*}{ Mortar } & \multicolumn{4}{|c|}{ Heating } & \multicolumn{4}{|c|}{ Cooling } \\
\hline & & $\begin{array}{c}\text { Peak } \\
\text { Demand } \\
(K W h)\end{array}$ & $\begin{array}{c}\text { Peak } \\
\text { Reduction } \\
(\%)\end{array}$ & $\begin{array}{c}\text { Total } \\
\text { (KWh/Year) }\end{array}$ & $\begin{array}{c}\text { Annual } \\
\text { Reduction } \\
(\%)\end{array}$ & $\begin{array}{c}\text { Peak } \\
\text { Demand } \\
(\mathrm{KWh})\end{array}$ & $\begin{array}{c}\text { Peak } \\
\text { Reduction } \\
(\%)\end{array}$ & $\begin{array}{c}\text { Total } \\
\text { (KWh/Year) }\end{array}$ & $\begin{array}{c}\text { Annual } \\
\text { Reduction } \\
(\%)\end{array}$ \\
\hline \multirow{4}{*}{$\mathrm{Z1}$} & $\mathrm{mR}$ & 2.97 & & 2667 & & 4.14 & & 1871 & \\
\hline & $\mathrm{m} 25$ & 2.85 & $4.3 \%$ & 2460 & $7.8 \%$ & 3.78 & $8.7 \%$ & 1721 & $8.0 \%$ \\
\hline & $\mathrm{m} 50$ & 2.75 & $7.6 \%$ & 2259 & $15.3 \%$ & 3.64 & $12.2 \%$ & 1689 & $9.7 \%$ \\
\hline & $\mathrm{mR}$ & 3.39 & & 7047 & & 6.45 & & 3746 & \\
\hline \multirow[t]{3}{*}{$\mathrm{Z} 2$} & $\mathrm{~m} 25$ & 3.31 & $2.6 \%$ & 6806 & $3.4 \%$ & 6.14 & $4.8 \%$ & 3462 & $7.6 \%$ \\
\hline & $\mathrm{m} 50$ & 3.22 & $5.1 \%$ & 6557 & $7.0 \%$ & 6.01 & $6.8 \%$ & 3380 & $9.8 \%$ \\
\hline & $\mathrm{mR}$ & 2.74 & & 5611 & & 4.47 & & 2953 & \\
\hline \multirow[t]{3}{*}{$\mathrm{Z3}$} & $\mathrm{m} 25$ & 2.70 & $1.5 \%$ & 5477 & $2.4 \%$ & 4.23 & $5.4 \%$ & 2739 & $7.3 \%$ \\
\hline & $\mathrm{m} 50$ & 2.66 & $2.8 \%$ & 5339 & $4.8 \%$ & 4.13 & $7.6 \%$ & 2693 & $8.8 \%$ \\
\hline & $\mathrm{mR}$ & 0.92 & & 1403 & & 0.00 & & 0.00 & \\
\hline \multirow[t]{3}{*}{$\mathrm{Z} 4$} & $\mathrm{~m} 25$ & 0.92 & $0.6 \%$ & 1391 & $0.8 \%$ & 0.00 & - & 0.00 & - \\
\hline & $\mathrm{m} 50$ & 0.91 & $1.3 \%$ & 1364 & $2.7 \%$ & 0.00 & - & 0.00 & - \\
\hline & $\mathrm{mR}$ & 1.07 & & 1902 & & 0.00 & & 0.00 & \\
\hline \multirow[t]{3}{*}{ Z5 } & $\mathrm{m} 25$ & 1.07 & $0.4 \%$ & 1891 & $0.6 \%$ & 0.00 & - & 0.00 & - \\
\hline & $\mathrm{m} 50$ & 1.06 & $1.0 \%$ & 1863 & $2.1 \%$ & 0.00 & - & 0.00 & - \\
\hline & $\mathrm{mR}$ & 1.03 & & 1755 & & 0.00 & & 0.00 & \\
\hline \multirow[t]{3}{*}{ Z6 } & $\mathrm{m} 25$ & 1.03 & $0.3 \%$ & 1756 & $0.0 \%$ & 0.00 & - & 0.00 & - \\
\hline & $\mathrm{m} 50$ & 1.03 & $0.8 \%$ & 1739 & $0.9 \%$ & 0.00 & - & 0.00 & - \\
\hline & $\mathrm{mR}$ & 1.10 & & 3176 & & 0.00 & & 0.00 & \\
\hline \multirow[t]{2}{*}{$\mathrm{Z7}$} & $\mathrm{m} 25$ & 1.10 & $0.1 \%$ & 3187 & $-0.4 \%$ & 0.00 & - & 0.00 & - \\
\hline & $\mathrm{m} 50$ & 1.09 & $0.3 \%$ & 3178 & $-0.1 \%$ & 0.00 & - & 0.00 & - \\
\hline
\end{tabular}

It can be seen by these results that the thermal and energy benefits of using glass aggregate mortars are closely tied to the percentage of glass incorporated, the thermal zone and the dwelling's type of operation. The m50 mortar can imply an increase in the hours of comfort and lower indoor thermal oscillations to avoid overheating in zones 1, 2, 3 and 6 . When the dwelling operates with air-conditioning systems, the substantial differences of using these mortars would be in zones 1, 2 and 3 , with zone 2 producing the highest saving, with a total reduction of $857 \mathrm{kWh} /$ year, bearing in mind both heating and cooling. However, it should also be remarked that this material might have a controversial effect in the coldest zones, giving as a result a slight increment in the heating demand.

\section{Conclusions}

In this research, mortar blocks with doses of $25 \%(\mathrm{~m} 25)$ and $50 \%(\mathrm{~m} 50)$ of recycled glass aggregate were analyzed from a thermal point of view. This assumes a tangential vision to the traditional analysis based on mechanical behavior. The approach to the analysis focuses on social housing, using 21 models located in the 7 thermal representative zones of Chile. Using a methodology based on analyzing periodic thermal transmittance, adaptive comfort levels and energy demand, the thermal analysis is addressed holistically, making it possible to extrapolate this methodology to different construction solutions.

On considering thermal transmittance results, it can be pointed out that with the m50 solutions, this is reduced by $22 \%$, the decrement factor is reduced by $10 \%$, and the time shift increases by approximately one hour. Meanwhile, locations with a higher thermal amplitude between day and night like 6 (Lonquimay) and 3 (Santiago), both in winter and in summer, see significant reductions when compared with traditional solutions without a recycled glass aggregate.

Regarding thermal comfort, we can conclude that an increase is detected in the hours of comfort in all zones except in zone 7 (Punta Arenas), increasing $199 \mathrm{~h}$ in zone 1 (Antofagasta) with the m50 solution. The extension effect of hours of comfort and the reduction of distance, compared to the neutral temperature, is accentuated in zones 1 (Antofagasta), 2 (Valparaiso), 3 (Santiago) and 6 (Lonquimay). 
The m50 solution increases hours of comfort by almost $50 \%$ when compared with $\mathrm{m} 25$ and reduces the distance in respect to the neutral temperature by half.

Regarding energy demands, the most relevant finding is the reduction of the peak demand in all thermal zones, from $0.1 \%$ (heating) with $\mathrm{m} 25$ in zone 7 , to $12.2 \%$ (cooling) with $\mathrm{m} 50$ in zone 1 . The annual energy demand reduction is seen in zones 1 (Antofagasta), 2 (Valparaiso) and 3 (Santiago), with up to $15 \%$. On this occasion, the m50 reduces the demand by around $50 \%$, compared to the $\mathrm{m} 25$.

This research is a starting point to be valued in decision-making when it comes to implementing a construction solution with recycled materials in a country. In future work, the simulation results should be validated with actual prototypes. Further research is needed to generate an implementation methodology of new construction solutions which consider energy behavior, bearing in mind the energy poverty levels of social housing and that this cannot be done in any other way than with low environmental impact solutions.

Author Contributions: All the authors contributed equally to the present research. All authors have read and agreed to the published version of the manuscript.

Funding: This research as well as The APC were funded by National Agency for Research and Development (ANID) of Chile, grant number 1200551.

Acknowledgments: The authors would also like to acknowledge that this paper is part of the project "Conicyt Fondecyt Regular 1200551 - Energy poverty prediction based on social housing architectural design in the central and central-southern zones of Chile: an innovative index to analyze and reduce the risk of energy poverty" funded by the National Agency for Research and Development (ANID). In addition, we would like to acknowledge to the research group "Confort ambiental y pobreza energética (+CO-PE)" of the University of the Bío-Bío for supporting this research. Authors also wish to express their gratitude to the General Research Center at the University of Seville (CITIUS).

Conflicts of Interest: The authors declare no conflict of interest.

\section{References}

1. European Federation of Glass Packaging Makers Record Collection of Glass Containers for Recycling hits $76 \%$ in the EU-FEVE. Available online: https://feve.org/record-collection-of-glass-containers-for-recyclinghits-76-in-the-eu/ (accessed on 17 May 2020).

2. European Federation of Glass Packaging Makers Glass Recycling Statistics Year 2017. Available online: http://feve.org/about-glass/statistics/ (accessed on 17 May 2020).

3. Harder, J. Glass recycling-Current market trends. Recovery 2018, 5.

4. Hogland, W. Remediation of an old landsfill site. Environ. Sci. Pollut. Res. 2002, 9, 49-54. [CrossRef] [PubMed]

5. Saillio, M.; Frohard, F.; Chaussadent, T.; Divet, L.; Tagnit-Hamou, A. Durability of concrete with alternative supplementary cementitious materials. In Proceedings of the 10th ACI/RILEM International Conference on Cementitious Materials and Alternative Binders for Sustainable Concrete, Montreal, QU, Canada, 2-4 October 2017.

6. Aliabdo, A.A.; Abd Elmoaty, A.E.M.; Aboshama, A.Y. Utilization of waste glass powder in the production of cement and concrete. Constr. Build. Mater. 2016, 124, 866-877. [CrossRef]

7. Salim, M.N.; Jenal, R.B.; Ismail, M.P. Reflected guided wave in plate with flaw using civa simulation software. In Proceedings of the 6th International Engineering Conference (ENCON 2013), Kuching Sarawak, Malaysia, 4 July 2013; pp. 978-981.

8. Chen, Z.; Wang, Y.; Liao, S.; Huang, Y. Grinding kinetics of waste glass powder and its composite effect as pozzolanic admixture in cement concrete. Constr. Build. Mater. 2020, 239, 117876. [CrossRef]

9. Chen, G.; Lee, H.; Young, K.L.; Yue, P.L.; Wong, A.; Tao, T.; Choi, K.K. Glass recycling in cement production-an innovative approach. Waste Manag. 2002, 22, 747-753. [CrossRef]

10. Idir, R.; Cyr, M.; Tagnit-Hamou, A. Use of fine glass as ASR inhibitor in glass aggregate mortars. Constr. Build. Mater. 2010, 24, 1309-1312. [CrossRef]

11. Carles-Gibergues, A.; Cyr, M.; Moisson, M.; Ringot, E. A simple way to mitigate alkali-silica reaction. Mater. Struct. Constr. 2008, 41, 73-83. [CrossRef] 
12. Cassar, J.; Camilleri, J. Utilisation of imploded glass in structural concrete. Constr. Build. Mater. 2012, 29, 299-307. [CrossRef]

13. Shayan, A.; Xu, A. Value-added utilisation of waste glass in concrete. Cem. Concr. Res. 2004, 34, 81-89. [CrossRef]

14. Sikora, P.; Augustyniak, A.; Cendrowski, K.; Horszczaruk, E.; Rucinska, T.; Nawrotek, P.; Mijowska, E. Characterization of mechanical and bactericidal properties of cement mortars containingwaste glass aggregate and nanomaterials. Materials (Basel) 2016, 9, 701. [CrossRef] [PubMed]

15. Poon, C.S.; Cheung, E. NO removal efficiency of photocatalytic paving blocks prepared with recycled materials. Constr. Build. Mater. 2007, 21, 1746-1753. [CrossRef]

16. Ajdukiewicz, A.; Kliszczewicz, A. Influence of recycled aggregates on mechanical properties of HS/HPC. Cem. Concr. Compos. 2002, 24, 269-279. [CrossRef]

17. Mohajerani, A.; Vajna, J.; Cheung, T.H.H.; Kurmus, H.; Arulrajah, A.; Horpibulsuk, S. Practical recycling applications of crushed waste glass in construction materials: A review. Constr. Build. Mater. 2017, 156, 443-467. [CrossRef]

18. Kumarappan, N. Partial replacement cement in concrete using waste glass. Int. J. Eng. Res. Technol. 2013, 2, 1880-1883.

19. McNeil, K.; Kang, T.H.K. Recycled concrete aggregates: A review. Int. J. Concr. Struct. Mater. 2013, 7, 61-69. [CrossRef]

20. De Castro, S.; de Brito, J. Evaluation of the durability of concrete made with crushed glass aggregates. J. Clean. Prod. 2013, 41, 7-14. [CrossRef]

21. Lu, J.X.; Zhou, Y.; He, P.; Wang, S.; Shen, P.; Poon, C.S. Sustainable reuse of waste glass and incinerated sewage sludge ash in insulating building products: Functional and durability assessment. J. Clean. Prod. 2019, 236, 117635. [CrossRef]

22. Alani, A.; MacMullen, J.; Telik, O.; Zhang, Z.Y. Investigation into the thermal performance of recycled glass screed for construction purposes. Constr. Build. Mater. 2012, 29, 527-532. [CrossRef]

23. Sikora, P.; Horszczaruk, E.; Skoczylas, K.; Rucinska, T. Thermal properties of cement mortars containing waste glass aggregate and nanosilica. Procedia Eng. 2017, 196, 159-166. [CrossRef]

24. Xiao, Z.; Ling, T.C.; Poon, C.S.; Kou, S.C.; Wang, Q.; Huang, R. Properties of partition wall blocks prepared with high percentages of recycled clay brick after exposure to elevated temperatures. Constr. Build. Mater. 2013, 49, 56-61. [CrossRef]

25. Khan, M.N.N.; Saha, A.K.; Sarker, P.K. Reuse of waste glass as a supplementary binder and aggregate for sustainable cement-based construction materials: A review. J. Build. Eng. 2020, 28, 101052. [CrossRef]

26. Flores-Alés, V.; Jiménez-Bayarri, V.; Pérez-Fargallo, A. Influencia de la incorporación de vidrio triturado en las propiedades y el comportamiento a alta temperatura de morteros de cemento. Boletín Soc. Española Cerámica Vidr. 2018, 57, 257-265. [CrossRef]

27. Flores-Alés, V.; Alducin-Ochoa, J.M.; Martín-del-Río, J.J.; Torres-González, M.; Jiménez-Bayarri, V. Physical-mechanical behaviour and transformations at high temperature in a cement mortar with waste glass as aggregate. J. Build. Eng. 2020, 29, 101158. [CrossRef]

28. Yilmaz, Z. Evaluation of energy efficient design strategies for different climatic zones: Comparison of thermal performance of buildings in temperate-humid and hot-dry climate. Energy Build. 2007, 39, 306-316. [CrossRef]

29. Rodrigues, E.; Fernandes, M.S.; Gaspar, A.R.; Gomes, Á.; Costa, J.J. Thermal transmittance effect on energy consumption of Mediterranean buildings with different thermal mass. Appl. Energy 2019, 252, 113437. [CrossRef]

30. Dodoo, A.; Gustavsson, L.; Sathre, R. Effect of thermal mass on life cycle primary energy balances of a concrete-and a wood-frame building. Appl. Energy 2012, 92, 462-472. [CrossRef]

31. AENOR. UNE-EN ISO 13786:2011. Prestaciones Térmicas de los Productos y Componentes para Edificación. Características Térmicas Dinámicas. Métodos de Cálculo; Asociacion Espanola de Normalizacion: Madrid, Spain, 2011.

32. AENOR. UNE-EN ISO 6946:2012. Componentes y Elementos para la Edificación. Resistencia Térmica y Transmitancia Térmica. Método de Cálculo; Asociacion Espanola de Normalizacion: Madrid, Spain, 2012.

33. Stazi, F.; Ulpiani, G.; Pergolini, M.; Di Perna, C. The role of areal heat capacity and decrement factor in case of hyper insulated buildings: An experimental study. Energy Build. 2018, 176, 310-324. [CrossRef] 
34. Rubio-Bellido, C.; Pérez-Fargallo, A.; Pulido-Arcas, J.A.; Trebilcock, M. Application of adaptive comfort behaviors in Chilean social housing standards under the influence of climate change. Build. Simul. 2017, 10, 933-947. [CrossRef]

35. MINVU Estadisticas Históricas. Available online: http://www.observatoriohabitacional.cl/ (accessed on 28 April 2016).

36. MINVU. MINVU DS 01. Reglamento del Sistema Integrado de Subsidio Habitacional; MINVU: Santiago de Chile, Chile, 2011.

37. MINVU. MINVU DS 49. Reglamento del Programa Fondo Solidario de Elección de Vivienda; MINVU: Santiago de Chile, Chile, 2011.

38. MOP Decreto con Fuerza de Ley $\mathrm{N}^{\circ} 2$ Sobre Plan Habitacional. Available online: http://www.sii.cl/pagina/ jurisprudencia/legislacion/basica/dfl2_1.htm (accessed on 16 November 2016).

39. MINVU. MINVU DS 47. Ordenanza General de la Ley General de Urbanismo y Construcciones; MINVU: Santiago de Chile, Chile, 1992.

40. MINVU (Ed.) Artículo 4.1.10. Exigencias de acondicionamiento térmico de la Ordenanza general de urbanismo y construcciones. In DS 47 Ordenanza General de la Ley General de Urbanismo y Construcciones; MINVU: Santiago, Chile, 2007.

41. MINVU and Building Research Establishment. Estándares de Construcción Sustentable para Viviendas en Chile; MINVU and Building Research Establishment: Santiago de Chile, Chile, 2018.

42. Pérez-Fargallo, A.; Pulido-Arcas, J.A.; Rubio-Bellido, C.; Trebilcock, M.; Piderit, M.B.; Attia, S. Development of a new adaptive comfort model for low income housing in the central-south of chile. Energy Build. 2018, 178, 94-106. [CrossRef]

43. Porras-Salazar, J.A.; Contreras-Espinoza, S.; Cartes, I.; Piggot-Navarrete, J.; Pérez-Fargallo, A. Energy poverty analyzed considering the adaptive comfort of people living in social housing in the central-south of Chile. Energy Build. 2020, 223, 110081. [CrossRef]

44. American Society of Heating, R.A.C.E. (ASHRAE) (Ed.) ASHRAE Standard 55-2017. Thermal Environmental Conditions for Human Occupancy; ASHRAE Inc. American Society of Heating, Refrigerating and Air Conditioning Engineers: Atlanta, GA, USA, 2017; ISBN 1041-2336.

45. Flores-Alés, V.; Martín-del-Río, J.J.; Alducin-Ochoa, J.M.; Torres-González, M. Rehydration on high temperature-mortars based on recycled glass as aggregate. J. Clean. Prod. 2020, 275, 124139. [CrossRef]

46. Blumm, J.; Lindeman, A.; Niedrig, B. Measurement of the thermophysical properties of an NPL thermal conductivity standard Inconel 600. High Temp. Press. 2003, 35/36, 621-626. [CrossRef]

47. Carslaw, H.S.; Jaeger, J.C. Conduction of Heat in Solids, 2nd ed.; Oxford Clarendon Press: Oxford, UK, 1959.

48. Ministerío de Vivienda y Urbanísmo. Artículo 4.1.10. Exigencias de Acondicionamiento Térmico de la Ordenanza General de Urbanismo y Construcciones; Ministerío de Vivienda y Urbanísmo: Santiago, Chile, 2011.

49. Ministerío de Vivienda y Urbanísmo. Artículo 4.1.10. Manual de Aplicación. Reglamentación Térmica. Ordenanza General de Urbanísmo y Construcciones; Ministerío de Vivienda y Urbanísmo: Santiago, Chile, 2016.

50. Nicol, J.F.; Humphreys, M.A. Adaptive thermal comfort and sustainable thermal standards for buildings. Energy Build. 2002, 34, 563-572. [CrossRef]

51. Escandón, R.; Suárez, R.; Sendra, J.J.; Ascione, F.; Bianco, N.; Mauro, G.M. Predicting the impact of climate change on thermal comfort in a building category: The Case of Linear-type Social Housing Stock in Southern Spain. Energies 2019, 12, 2238. [CrossRef]

52. CEN. Indoor Environmental Input Parameters for Design and Assessment of Energy Performance of Buildings Addressing Indoor Air quality, Thermal Environment, Lighting and Acoustics; CEN: Brussels, Belgium, 2017; Volume 44, EN 16798.

53. HTflux-Hygrig and Thermal Simulation Software. Available online: https://www.htflux.com/en/ (accessed on 17 May 2020).

Publisher's Note: MDPI stays neutral with regard to jurisdictional claims in published maps and institutional affiliations. 